\title{
Innovative Technologies and Social Responsibility of Business: Analysis of Possibilities
}

\author{
Mykhailo Luchko, Liudmyla Holinach, Iryna Shchyrba, Nataliia Muzhevych
}

Ternopil National Economic University, Ternopil, Ukraine

\begin{abstract}
The mechanism of organization and prediction regarding the main indicators of innovative business on the example of disposable cookware production made from bran is offered in the article. The statistical study of the potential demand for this cookware is conducted. The three-factor linear dependence function is constructed. The relationship between the change in demand for disposable cookware and the change in the average income of the population per month, the change in demand for this cookware and the change in the number of people who understand the essence of global problems comprising the humanity frame by having an active social position, the change in demand for disposable cookware with changes in price and product are also researched. Digital material and empirical data of Ukrainian enterprises are used in this study.
\end{abstract}

Keywords - three-factor linear dependence function, production potential analysis.

\section{Introduction}

The regularities regarding dynamic economic development and the formation of effectively functioning enterprises testify to the exceptional advantage in terms of economic development in the national and world markets of innovative industries.

DOI: 10.18421/TEM92-34

https://doi.org/10.18421/TEM92-34

Corresponding author: Mykhailo Luchko, Department of Economic Expertise and Business Audit, Ternopil National Economic University,Ternopil, Ukraine.

Email: $\underline{m}$ luchko@ukr.net

Received: 14 February 2020.

Revised: 03 May 2020.

Accepted: 09 May 2020.

Published: 27 May 2020.

(c) BY-NC-ND (C) 2020 Mykhailo Luchko at al; published by UIKTEN. This work is licensed under the Creative Commons Attribution-NonCommercial-NoDerivs 4.0 License.

The article is published with Open Access at www.temjournal.com
Traditionally, innovation has been considered to be a major driver of economic growth, which is an undeniable fact.

At the same time, in many countries, the proportion of enterprises doing business creating an innovative product or technology is declining. One of the reasons is the public opinion that to create a product has no analogues, or to introduce significantly new technologies in the management process, business organization or technological, production processes requires considerable investment resources and material resources. Our hypothesis does not deny the fact of the need to attract investment, but partially refutes it.

The essences of our beliefs are:

1. The basis of innovative production is intelligence combined with the social purpose of innovation activity. That is, the main driving factors behind the creation of a certain innovation are mental abilities, which are manifested in creativity, innovation, the ability to create new and unlike analogues, the motivator of which is the desire to get economic benefits in the form of income, profit, and the desire is equal to the need to create benefits in the scope of social or corporate problem;

2. Given the scarcity of resources for the development of innovations in the field of economy, it is necessary to initiate institutional support to create opportunities for people who have ideas related to solving specific social problems. It can be manifested in the formation of institutions that provide assistance (educational, organizational, and financial) in the process of implementing mini-projects of innovative nature with social implications. It is worth noting the first steps towards the establishment of innovation support institutes, which is to approve the Strategy of development in the sphere of innovative activity for the period till 2030 by the Ukrainian government.

There is reason to believe that a business that utilizes absolutely the full range of innovative products and tools is effective. Accordingly, 
innovations exist in virtually every element of the business, they are in the details. The main thing is not only their economic efficiency, but in many cases social and environmental focuses on the future.

In view of the foregoing, we believe that the advancement of innovation activity, the job market and competitiveness are only possible together with the solution of global social and environmental problems, and first of all such as climate change and scarcity of natural resources.

\section{Literature Review}

In order to achieve the goals of the research it should be structured in the following areas: innovation and their social responsibility, economic and social efficiency of innovative business projects, innovations in the processes of creating and replacing plastic waste, creation of environmentally friendly disposable cookware, calculation of economic efficiency of socially oriented business projects, and unresolved issues that should be addressed in scientific research.

The first ideas of corporate social responsibility were expressed by Chester Bernards in the book "Performing Functions" (1939), by J. Clark in the publication "Social Control of Business" (1939). H. Baven, J. Beckman pointed out the need for adherence and advantages of such a concept, $\mathrm{K}$. Davis, T. Bosch explained its essence and scope [1]. A. Carroll [2], [3], [4] examined the development of socially responsible activity of enterprises in the historical aspect; D. Baron [5] became a researcher in the market of social services.

The issues of defining corporate social responsibility were explored by Dahlsrud A. (2006). $\mathrm{He}$ pointed out that, despite numerous efforts to achieve a clear and unbiased definition, there was still some confusion and the need to construct it in a socially specific context [6]. Gond J.-P. (2011) explored corporate social responsibility in retrospect and perspective and defined its life cycle as a substantially contested concept [7].

Considerable attention has been paid to the economic and social effectiveness of innovative business projects. Thus, Luchko M. (2017) points out that the world is rapidly changing under the influence of the new economy, digital knowledge, advanced communication technologies, the emergence of "techno-sapiens" [8]. Robotization in the economy, research of artificial intelligence, impose the need to change the paradigm of state formation, and to constantly improve the mental level of the productive forces of any country, regardless of the stage of its development. It is noted that innovative development is the only way of European transformation of Ukraine. It has no alternative. Its course is impossible without diversification of the Ukrainian economy. The recipe for its recovery lies in the consciousness of the population and in the changes of paradigm principles. Without changing the mentality of the population, no institutional transformation will succeed.

An article by Silvia Blajberg Schaffel, Emilio Lèbre La Rovere (2010) illustrates the idea that may be the beginning of eco-social efficiency [9]. The equalization of eco-efficiency and the linking of business with sustainable development are clearly limited, especially with the new paradigms of social responsibility. Practice has shown that the contribution of the private sector to sustainable development can go far beyond the scope of pollution control. The authors point out that ecoefficiency needs to be more meaningful so that it can support the pursuit of sustainable development. This requires the inclusion of social aspects that lead to a certain eco-social effectiveness.

The Social Innovation A Decade of Changes (2014) report indicates that many initiatives and measures have been taken in recent years to develop pragmatic, common social and environmental problems. Conversion analysis shows that countries are undergoing economic renewal and institutional change. The answer is that business should pay attention not to financial profit, but rather to real social needs and problems, which is a prerequisite for reviewing production systems and redistribution. In this context, social innovation is not only a response to pressing social needs and addressing the societal challenges of climate change, aging or poverty, but is also a mechanism for achieving systemic change.

Aygerim Abeldanova's (2015) article deals with the regulation of innovation activity [10]. The state comprising innovative development of enterprises at the present stage is analyzed. The basic approaches to the complex estimation regarding efficiency of innovative activity of the enterprise are considered and the most acceptable, corresponding to modern conditions is offered.

Frank Boons and others (2013) noted that sustainable development requires radical and systemic innovation [11]. Such innovations can be more effectively created and explored based on the concept of business models. This concept provides enterprises with a holistic framework for delivering and implementing sustainable innovation. Researchers are offered an analytical tool that allows them to evaluate the relationship between the various aspects that enterprises combine to create environmental, economic and social value.

Michela Piccarozzi (2017) examines the social responsibility of innovation in Start-Ups [12]. The article points out that those social startups are of particular interest among innovative startups. The 
purpose of this research is twofold: to analyze the relationship between social innovation and business sustainability, and to try to understand how to promote social innovation sustainability. Denise Wallace (2014) points to social innovation and notes that corporate sustainability is a corporate response to a sustainable future based on eco-efficiency and innovative solutions to engage all people, especially developing countries, in the world economy [13]. Victor Danciu (2013) points to the need to calculate environmental performance as a necessary attribute of sustainable business development and proposes four strategies that a business could develop and implement in order to increase its sustainability in the future [14].

It should be noted that explaining the term "innovation" and forming ratings of innovation activity, researchers do not go beyond the social component. For example, in accordance with the methodology for assessing the level of innovation implementation in European countries, one of the elements for the assessment is Innovations friendly environment.

This is not an exclusive list of responses to the challenges that drive innovation, but they also emphasize the importance of the topic chosen and its relevance.

\section{Objective of the Study}

The purpose of the article is to explore the implementing possibilities within innovative projects and their social responsibility on the example of the production of disposable cookware from cereal waste. In our opinion, this will, in combination with other measures, solve environmental problems of combating plastic and paper waste, conservation of forest resources, and it will avoid the disposal of unusable cereal waste for human consumption. In addition, the introduction of such innovations will also solve the following problems: it will stimulate the dynamics of economic potential growth and allow developing the market of alternative social and eco-products.

To address the basic idea of our research, we propose the following hypotheses - assumptions that we will test experimentally for a possible solution to the problem. First, whether the introduction of innovations will have a dominant influence on the demand function by factors such as average income of the population, active social position of the population, the price of the substitute product. Secondly, if the introduction of innovations can increase (change) the factor regarding the social position of the population, and if the two other factors do not change, how they will increase (change) the demand for the social substitute product.

\section{Research Methodology}

Methodologically, our thoughts are set out in the following order. First, we list the common starting points of our arguments - the preconditions and conditions of our vision. In the next stage, we attempted to present our views on the identified range of issues. In the final phase, we settled on a model of a possible solution to the problem, and tested the theoretical and methodological material to verify the proposal.

The research problem is presented, the need to test the hypotheses accepted in the study, the need to develop a model have led to the division of the research process into specific stages and the choice of appropriate methods in each of them. Initially, we used the following scientific methods: literature review and analysis, direct observation, and documentary method. Further on, we used such research methods as surveys and interviews. The information and knowledge obtained were processed using comparison methods (sample analysis, retrospective analysis). The quantitative and qualitative empirical data collected were processed using: statistical calculations, significance tests, and correlations between estimates.

In the process of writing the article, a systematic approach was applied as one of the main methods of scientific researches; methods of economic and mathematical modeling, regression dependencies, and methods of analogies, retrospective analysis, and classical method of hypotheses were used.

To obtain sound results of the research such scientific methods have been used: historical - to interpret and analyze the development of the social function of business, concretization - in the process of analysis of rating indicators, statistics, analysis and interpretation - to determine the social mission and economic goals of innovation and to create a social start-up, dialectical, logical - to study the factors that influence the potential demand for products (disposable tableware), statistical (questionnaire) - during the study of the dynamics of changes in demand for disposable tableware; formalization, economic and mathematical modeling - to develop a methodology for analyzing the demand function for goods.

Based on the questionnaire, we have formed a demand function. To estimate the dependence of demand for products on these factors, the type of dependence was determined and a multifactor model of dependence comprising the demand function on variables was constructed. Based on the constructed demand function, the relationship between the variables is determined and the level of demand depends on a number of factors. 


\section{Result / Analysis}

It has been researched that during the history of mankind has been produced 8.3 billion tons of plastic, half of this amount - in the last 13 years. Only $15 \%$ of plastic goes to recycling, the rest (7 billion tones) remains in landfills and reservoirs. If the situation is not stopped, by 2050, plastic in the oceans will have more than fish. According to the European Commission data, $70 \%$ of all plastic waste that goes into the oceans is disposable cookware. Prohibitions on the use of plastic will create conditions for the use of paper, which means increased use of forest resources, given the continued growth of catering, catering, and street food.

Selection, the production of disposable cookware with the reproduction of different cultural products requires problems in dealing with plastic waste, the regeneration of forest resources is also an original innovative production that can be reused (and possibly offered for reuse and re-sold), and animal feed. Most importantly, such utensils are organic products made with the help of cereals, water and heat and press, which is not technologically complicated.

In order to understand the factors that influence the potential of innovative production of disposable cookware, we first analyzed the level of potential demand for the products offered. To this end, we conducted a sociological survey among the population of different ages of the city of Ternopil (Ternopil region, Ukraine), the results of which are presented in Table 1. 1,348 people aged 13 to 55 were interviewed. A set of flat plates with a diameter of 22 centimeters is taken as the basis for determining the price, and 10 plates are included in the set. Please note that 24 UAH are \$ 1 (USA).

Table 1. Survey results

\begin{tabular}{|c|c|c|}
\hline Question & $\begin{array}{c}\text { Interviewees } \\
\text { aged } 13-25 \\
\text { years }\end{array}$ & $\begin{array}{c}\text { Interviewees } \\
\text { aged } 25-55 \\
\text { years }\end{array}$ \\
\hline $\begin{array}{l}\text { Specify your average income, } \\
\text { UAH }\end{array}$ & 5736 & 12472 \\
\hline $\begin{array}{l}\text { Do you use disposable } \\
\text { cookware? }\end{array}$ & $83 \%$ - yes & $92 \%$ - yes \\
\hline $\begin{array}{l}\text { What kind of cookware do } \\
\text { you buy? }\end{array}$ & $\begin{array}{l}17 \% \text { - plastic } \\
83 \% \text { - paper }\end{array}$ & $\begin{array}{l}12 \% \text { - plastic } \\
88 \% \text { - paper }\end{array}$ \\
\hline $\begin{array}{l}\text { Do you know about the } \\
\text { existence of cookware made } \\
\text { from bran and what problem } \\
\text { can be solved by introducing } \\
\text { these products to the market? }\end{array}$ & $\begin{array}{c}41 \%-\text { yes } \\
59 \% \text { - no }\end{array}$ & $\begin{array}{l}34 \%-\text { yes } \\
66 \%-\text { no }\end{array}$ \\
\hline $\begin{array}{l}\text { Would you buy cookware } \\
\text { from domestic producers? }\end{array}$ & $\begin{array}{l}52 \%-\text { yes } \\
48 \% \text { - no }\end{array}$ & $\begin{array}{l}46 \%-\text { yes } \\
54 \% \text { - no }\end{array}$ \\
\hline $\begin{array}{l}\text { At what marginal price would } \\
\text { you buy cookware made from } \\
\text { bran of a domestic producer? } \\
\text { - } 20-30 \text { UAH per set } \\
\text { - 30-40 UAH per set } \\
\text { - 40-50 UAH per set } \\
\text { - 50-60 UAH per set } \\
\text { - 60-70 UAH per set } \\
\text { - } 100 \text { UAH per set }\end{array}$ & $\begin{array}{l}\text { an average of } \\
20 \mathrm{UAH} \text { per set }\end{array}$ & $\begin{array}{l}\text { an average of } \\
40 \mathrm{UAH} \text { per set }\end{array}$ \\
\hline
\end{tabular}

Based on the questionnaire, a demand function is formed. It is determined that the main factors influencing the sales volume of disposable tableware in Ternopil are: the income of a person per month, the level of social position of a person, the price of edible disposable cookware from bran which the buyers are ready to pay when buying a product. The statistical results are shown in Table 2.

Table 2. Factors influencing the demand function of disposable cookware

\begin{tabular}{|c|c|c|c|c|}
\hline 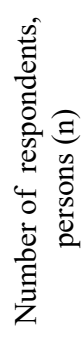 & 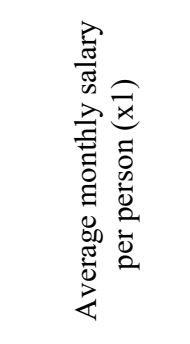 & 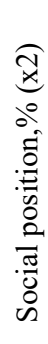 & 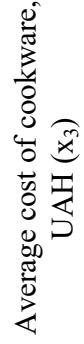 & 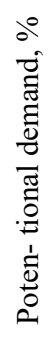 \\
\hline $\begin{array}{l}264 \\
383 \\
372 \\
329\end{array}$ & $\begin{array}{c}\text { till } 4000 \\
4000-8000 \\
8000-12000 \\
12000 \text { and } \\
\text { more }\end{array}$ & $\begin{array}{l}14 \\
38 \\
46 \\
54\end{array}$ & $\begin{array}{l}20 \\
23 \\
30 \\
50\end{array}$ & $\begin{array}{c}9 \\
27 \\
64 \\
78\end{array}$ \\
\hline
\end{tabular}

It is found that the magnitude of the error of sociological achievement with regard to design effect at a probability of 0.9545 is $4.1 \%$. To determine the change in demand from the change in the above factors, the table material was transformed into table 3.

Table 3. The listed factors of influence on the function of demand for disposable cookware

\begin{tabular}{|c|c|c|c|c|}
\hline 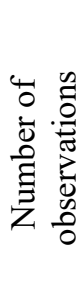 & 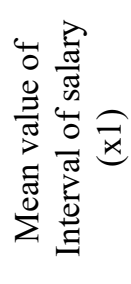 & 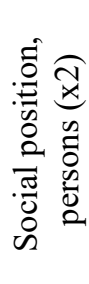 & 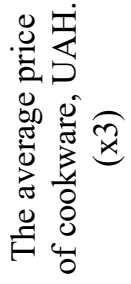 & 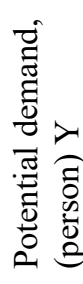 \\
\hline 1 & 2000 & 37 & 20 & 24 \\
\hline 2 & 6000 & 146 & 23 & 103 \\
\hline 3 & 10000 & 171 & 30 & 238 \\
\hline 4 & 14000 & 178 & 50 & 257 \\
\hline
\end{tabular}

To estimate the dependence of demand for products on these factors, the type of dependence was determined and a multifactor model of the demand function for variables was constructed. By graphically showing the line of change in potential demand for products from changes in the average monthly income of the population (Fig. 1), changes in the level of awareness among the population about the problem that can be used for eating utensils (Fig. 2) and changes in the price of dishes that buyers are willing to pay (Fig. 3), we trace a direct linear relationship between the factors and the productive trait. 


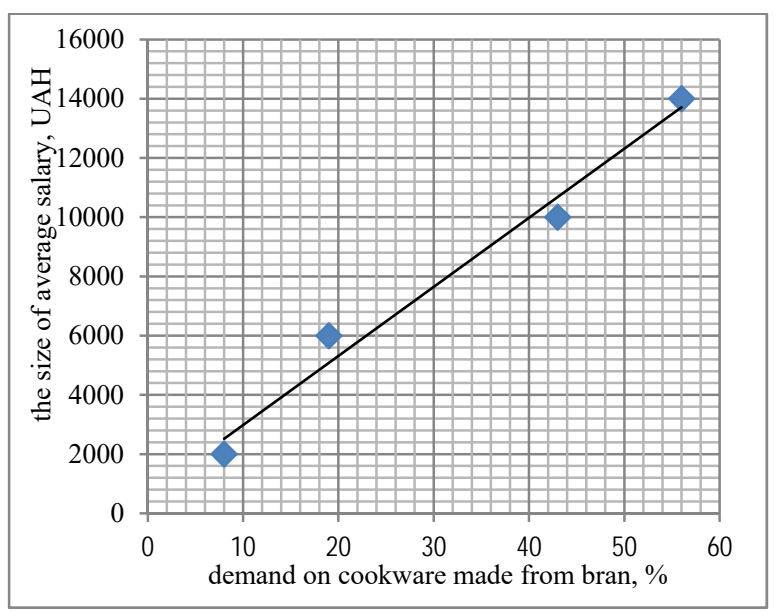

Figure 1. Dependence of potential demand on the average salary of the population

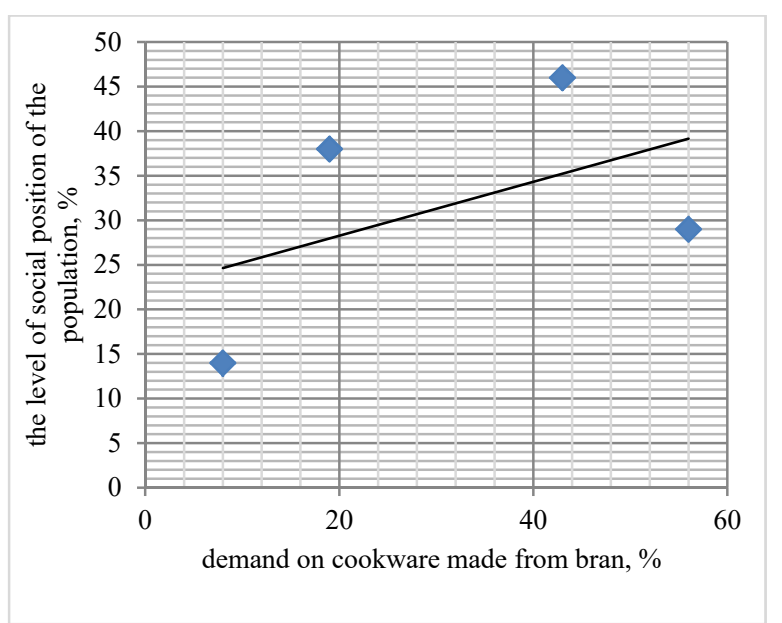

Figure 2. Dependence of potential demand on the social position of the population

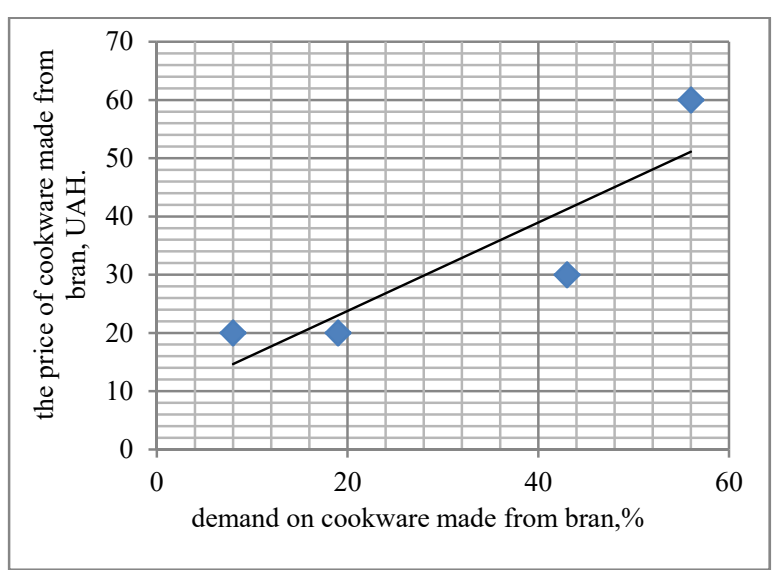

Figure 3. Dependence of potential demand on the change in the price of cookware

In addition to the graphic material, before constructing the demand function, it is necessary to determine the link density between the variables, that is, to set the level of demand for each of the factors. For this purpose, it is necessary to use values of pair and partial correlation coefficients, and also to compare the obtained results with the magnitude of correlation coefficient according to "Chaddock Table".

The even correlation coefficient is calculated by the formula:

$$
r_{y x}=\frac{\sum x y-\frac{\sum x \sum y}{n}}{\sqrt{\left(\sum x^{2}-\frac{\left(\sum x\right)^{2}}{n}\right)\left(\sum y^{2}-\frac{\left(\sum y\right)^{2}}{n}\right)}},
$$

$\mathrm{X}$ - factors of influence,

$y$ - the dependent variable (potential demand), $\mathrm{n}$ - the number of observations.

According to our research:

$$
\begin{array}{r}
r_{y x_{1}}=0,97 \\
r_{y x_{2}}=0,90 \\
r_{y x_{3}}=0,82 \\
r_{x_{i} x_{j}}= \\
\text { According to our } \\
r_{x_{1} x_{2}}=0,88 \\
r_{x_{1} x_{3}}=0,93 \\
r_{x_{2} x_{3}}=0,67
\end{array}
$$$$
r_{x_{i} x_{j}}=\frac{\sum x_{i} x_{j}-\frac{\sum x_{i} \sum x_{j}}{n}}{\sqrt{\left(\sum x_{i}{ }^{2}-\frac{\left(\sum x_{i}\right)^{2}}{n}\right)\left(\sum x_{j}^{2}-\frac{\left(\sum x_{j}\right)^{2}}{n}\right)}}
$$

According to our research:

The partial correlation coefficient is calculated by the formula:

$$
\begin{gathered}
r_{y x_{i\left(x_{j}\right)}}=\frac{r_{y x_{i}}-r_{y x_{j}} r_{x_{i} x_{j}}}{\sqrt{\left(1-r^{2} y x_{j}\right)\left(1-r^{2} x_{i} x_{j}\right)}}, \\
r_{y x_{j\left(x_{i}\right)}}=\frac{r_{y x_{j}}-r_{y x_{j}} r_{x_{i} x_{j}}}{\sqrt{\left(1-r^{2} y x_{i}\right)\left(1-r^{2} x_{i} x_{j}\right)}} \\
r_{y x_{1\left(x_{2}\right)}}=0,86 \\
r_{y x_{1\left(x_{3}\right)}}=0,98 \\
r_{y x_{2\left(x_{1}\right)}}=0,4 \\
r_{y x_{2\left(x_{3}\right)}}=0,83 \\
r_{y x_{3\left(x_{1}\right)}}=-0,91 \\
r_{y x_{3\left(x_{2}\right)}}=0,67
\end{gathered}
$$

According to the calculations, there is a significant correlation between the change in demand for disposable cookware made from bran and the change in the average monthly income of the population (0.97), the significant relationship between the change in demand for disposable cookware made from bran and the change in the number of people who understand the essence of global problems humanity and have an active social position (0.90). There is a significant correlation between the change in demand for disposable cookware made from bran and the change in price and production (0.82). There is also a significant correlation between factors such as average per capita income per month and understanding of the planet's pollution problem with 
garbage and social position (0.88), the correlation between average per capita income per month and the price of bran products (0.93), a noticeable relationship between a factor that indicates a population's understanding for the problem of pollution of the Planet with debris and the social position of the population and a factor that indicates the price of bran products (0.67). That is, a significant change in the factor of income among the population causes a significant change in the factor of social position of the population, also a significant change in a factor of income in the population causes a significant change in the factor of the price regarding disposable cookware made from bran. The quantitative change of the factor of social position of the population has a significant effect on the change in the price of products made from bran, but not significant.

Analyzing the value of the partial correlation coefficients of the first order, we can note the following. Therefore, the impact of changes in the average income of the population on demand, given the factor of fluctuation of the social position of the population is strong (0.85), and if the factor of the price of goods is taken into account - very strong (0.98). Demand changes under the influence of changes in the number of people with an active social position, while at the same time changing the average income of the population for a month at a moderate rate $(0.40)$, and at the same time changing the price of cookware made from bran - strongly (0.83). Demand changes strongly under the influence of the change in the price of cookware while changing the average monthly income of the population $(-0.91)$, whereas the demand changes significantly, but not very much (0.67).

Based on the inference of the existence of a linear relationship, we show the dependence of demand on the above factors by means of a multiple regression equation with four unknown independent variables on a linear basis (Formula 5):

$$
Y=b+b_{1} x_{1}+b_{2} x_{2}+b_{3} x_{3},
$$

where $b, b_{1}, b_{2}, b_{3}$ are the parameters of the equation, $x_{1}$ is the average monthly income of the respondent, $\mathrm{x}_{2}$ is the percentage of respondents who understand the problem of environmental pollution and take an active social position, $x_{3}$ is the average price of the product that respondents agree to pay for a disposable cookware made from bran, $\mathrm{B}$ is the potential demand for products.

The unknowns are calculated using the method of least squares, which allows the values of unknown independent variables to be determined such that the sum of the squares of the distance comprising all points of the set to the regression line is the smallest (formulas 6,7).
Basic parameters of the multiple regression equation:

$$
\left\{\begin{array}{c}
\sum Y=n b+b \sum x \\
\sum Y x=b \sum x+b \sum x^{2}
\end{array}\right.
$$

$\mathrm{x}$ - an independent variable,

$\mathrm{Y}$ - dependent variable (demand),

$\mathrm{b}$ - equation parameters,

$\mathrm{n}$ - the number of observations.

Consequently, the system of equations for four unknown variables looks like:

$\left\{\begin{array}{c}\sum Y=n b+b_{1} \sum x_{1}+b_{2} \sum x_{2}+b_{3} \sum x_{3} \\ \sum Y x_{1}=b \sum x_{1}+b_{1} \sum x_{1}{ }^{2}+b_{2} \sum x_{1} x_{2}+b_{3} \sum x_{1} x_{3} \\ \sum Y x_{2}=b \sum x_{2}+b_{2} \sum x_{2}{ }^{2}+b_{1} \sum x_{1} x_{2}+b_{3} \sum x_{2} x_{3} \\ \sum Y x_{3}=b \sum x_{3}+b_{3} \sum x_{3}{ }^{2}+b_{1} \sum x_{1} x_{3}+b_{2} \sum x_{2} x_{3}\end{array}\right.$

The multiple regression equation to determine the function of demand for disposable cookware made from bran will be as follows:

$$
\left\{\begin{array}{c}
4 b+32000 b_{1}+532 b_{2}+123 b_{3}=622 \\
32000 b+33600000 b_{1}+5152000 b_{2}+1178000 b_{3}=66440 \\
532 b+5152000 b_{1}+83610 b_{2}+18128 b_{3}=102370 \\
123 b+1178000 b_{1}+18128 b_{2}+4329 b_{3}=22839
\end{array}\right.
$$

Solving a system of equations, we obtain the values of unknown variables per unit of factor that influence the potential demand for bran products.

$$
\begin{aligned}
& b_{3}=-10.54 \\
& b_{2}=-1.17 \\
& b_{1}=0.06 \\
& b=155.2
\end{aligned}
$$

Therefore, based on the calculations made, the potential demand function will look like this:

$$
Y=155.215+0.06 x_{1}-1.17 x_{2}-10.54 x_{3}
$$

According to the function, we calculate the coefficients of elasticity.

$$
\varepsilon_{\mathrm{i}}=b_{i} \frac{\sum x_{i}}{\sum y^{\prime}}
$$

$\varepsilon_{1}=3,09$

$\varepsilon_{2}=-1,0$

$\varepsilon_{3}=-2,08$

Thus, if the average wage of the population increases by $1 \%$, with the two other factors remaining unchanged, demand for disposable tableware from bran will increase by $3.09 \%$. Demand for products will decline by $2.08 \%$ as a result of raising the price of disposable cookware made from bran, with the remaining factors remaining unchanged. It is very important to note that the demand for bran products will decrease by $1.17 \%$ if 
the level of social position in the population increases by $1 \%$, while the other factors are unchanged.

This is explained by an Engel's law, which states that low-income populations will prefer essentials and lower-priced products will be in greater demand than higher-priced substitutes. It is also important to note that the statistics of the last interval range take into account the average salary of UAH 12000 , and the marginal (maximum salary) is $14300 \mathrm{UAH}$. Six respondents who described themselves as people with an active social position and all without exception would buy cookware made from bran. That is, the study focused on the middle-income population and did not take into account the actions of the rich. Such conclusions allow us to argue for a linear dependence of demand on the factors used. Thus, statistics show that, if the three factors are taken into account, demand for products will exist and grow in overall dynamics. At this stage of development of the national economy and society it will be on average $46.13 \%(9 * 264+383 * 27+372$ * $64+329 * 78) / 1348$ ) with an error of $4.1 \%$, which is very important to take into account in the process production of such cookware.

To determine the incentives and constraints, we have analyzed the technological and organizational features of the process of production of edible disposable cookware. Considering that the technology of the main raw material from which such cookware are made is bran (since bran makes up about $60-70 \%$ of the production cost of the product), the analysis of security of production of edible cookware with raw materials of domestic origin is made.

The analysis of statistics shows that there is an undeniable possibility of producing such cookware in the domestic market, since the share of cereals and legumes grown in Ukraine is $27.5 \%$ of the total volume of domestic agricultural production and is 14839 thousand hectares (in 2018). There has been a steady dynamics of the growth of sown areas of cereals and legumes in recent years. In addition, the volume of grain harvested in recent years has been increasing both in Ukraine as a whole (70057 thousand tones in 2018) and in the Ternopil region (Ukraine) (2632 thousand tones in 2018). Due to the fact that the average percentage of the formation of bran at the grinding of 1 ton of grain is $20-22 \%$, this indicates that the production of the main raw material - bran of domestic origin.

\section{Conclusion}

Thus, the organization and implementation of social innovative start-ups will allow accumulating investment resources for economic development. Implementation of such innovations will solve two problems at once: it will stimulate the dynamics of economic potential growth and will allow developing the market of alternative social and ecoproducts. This kind of goods will become effective substitutes for traditional products with their negative consequences of use. It will allow solving actual problems of society (resource saving, pollution, waste disposal, increase of welfare level, fight against illnesses, actualization of education and promotion of self-development, etc.).

In order to implement social innovative start-ups, it is important to understand the features of the market positioning regarding the product and the potential audience of its use. Therefore, formulating a production strategy based on determining the factors influencing potential demand should be the first task in the process of organizing such a business. Following the peculiarities of production activity, determining the main constraints in the effective organization and management of production activities will increase the efficiency of social innovation projects.

So that our methodology of organizing social startups to create and distribute innovative goods will help to intensify work in this field and simplify the mechanism of their implementation, in order to increase the efficiency of implementation of such projects.

\section{References}

[1]. Davis, K. (1960). Can business afford to ignore social responsibilities?. California management review, 2(3), 70-76.

[2]. Carroll, A.B. (2000). Ethical challenges for business in the new millennium: Corporate social responsibility and models of management morality. Business Ethics Quarterly, 10 (1), 33-42.

[3].Carroll, A.B. (1999). Corporate social responsibility: Evolution of a Definitional Construct. Business \& Society, 38 (3), 268-295.

[4]. Carroll, A. B. (1991). The pyramid of corporate social responsibility: Toward the moral management of organizational stakeholders. Business horizons, 34(4), $39-48$. 
[5]. Baron, D. P. (2009). A positive theory of moral management, social pressure, and corporate social performance. Journal of Economics \& Management Strategy, 18(1), 7-43.

[6].Dahlsrud, A. (2008). How corporate social responsibility is defined: an analysis of 37 definitions. Corporate social responsibility and environmental management, 15(1), 1-13.

[7]. Gond, J. P., \& Moon, J. (2011). Corporate social responsibility in retrospect and prospect: Exploring the life-cycle of an essentially contested concept. ICCSR Research Paper Series, 59, 1-40.

[8]. Luchko, M. (2017). Economy of Ukraine: The analysis of the innovative way of the development. Economics, Management and Sustainability, 2(2), 95-103.

[9]. Schaffel, S. B., \& La Rovere, E. L. (2010). The quest for eco-social efficiency in biofuels production in Brazil. Journal of Cleaner Production,18(16-17), 1663-1670.
[10]. Abeldanova, A. (2015). Key approaches to the integrated assessment of innovations at enterprises in Kazakhstan. Actual problems of economics, 7(169), 129-133.

[11]. Boons, F., Montalvo, C., Quist. J., Wagner, M. (2013). Sustainable innovation, business models and economic performance: an overview. Journal of Cleaner Production, 45, 1-8.

[12]. Piccarozzi, M. (2017). Does Social Innovation Contribute to Sustainability? The Case of Italian Innovative Start-Ups. Sustainability, 9(12), 2376.

[13]. Wallace, D. (2014). Human rights and business: a policy-oriented perspective. Martinus Nijhoff Publishers.

[14]. Danciu, V. (2013). The sustainable company: new challenges and strategies for more sustainability. Theoretical and Applied Economics, 20(9), 7-26. 